\title{
Effect of Schema Use in Solving Word Problems: Emphasis on Linguistic Difficulties
}

\author{
Namirah Fatmanissa ${ }^{1 *}$ (), Kusnandi Kusnandi ${ }^{2}$ (D), Dian Usdiyana ${ }^{2}$ (1)
}

${ }^{1}$ Sampoerna University, INDONESIA

${ }^{2}$ Universitas Pendidikan Indonesia, INDONESIA

*Corresponding Author: namirah.f@sampoernauniversity.ac.id

Citation: Fatmanissa, N., Kusnandi, K., \& Usdiyana, D. (2020). Effect of Schema Use in Solving Word Problems: Emphasis on Linguistic Difficulties. Contemporary Mathematics and Science Education, 1(2), ep20006. https://doi.org/10.30935/conmaths/8495

\begin{abstract}
Students' ability in solving mathematics word problems has been considered low, especially caused by difficulties in understanding information provided. Schema can be a helpful tool for students to face such difficulties. The aim of this research is to analyze the effectiveness of schema in resolving difficulties based on linguistic aspects constructing word problem (multiple representation systems, vocabulary, and grammar and syntax). A mixed method study of embedded experimental model was conducted with 69 participants of 11th grade students. Quantitative analysis to determine the effectiveness of schema was done by testing whether mathematical linguistic difficulties of treatment group was significantly lower than control students. Mathematical linguistic difficulties in each aspect were analyzed from the indicator-based coding of students' work on word problem test. Qualitative analysis was conducted by comparing experiment and control students' work on post-test. Experiment students showed significantly lower mathematical linguistic difficulties in each aspect compared to control ones. In general, schema is proven to be effective in resolving difficulties in each aspect. Qualitatively, students being taught schema showed more attention upon the whole information provided and were more self-directed in determining solving steps.
\end{abstract}

Keywords: linguistic difficulty, Mathematics, schema, word problem

Received: 9 Jun. 2020 Accepted: 1 Jul. 2020

\section{INTRODUCTION}

Word problem is a problem put in the context of daily life (Verschaffel, van Dooren, Greer, \& Mukhopadhyay, 2010), differentiating it from other types of problem. The context in word problem demands students to read, understand, and use their mathematical understanding. Word problem is not only written in the form of mathematical expression, but also is combined with daily language or picture. It needs complex solving steps i.e. reading, understanding, transforming into mathematical model, processing mathematical model, interpreting result to the context, and check the result (Reys, Lindquist, Lambdin, \& Smith, 2013; Ryan \& Williams, 2007; Verschaffel, van Dooren, Greer, \& Mukhopadhyay, 2010). This will need students to make more effort compared to non-word problems.

In Indonesia, several studies showed students low performance in solving word problems (Huda \& Kencana, 2013; Raharjo, 2008; Rindyana \& Chandra, 2013; Sutarni, 2011). Moreover, survey conducted by Center for Development and Empowerment of Mathematics Teacher and Educational staff (PPPPTK) stated that more than $50 \%$ of Indonesian teachers complained about students difficulties in solving word problems (Raharjo, 2008). Adding to that, word problems were often found in National Examination. Word problems were found in National Examination and categorized as "good", one level more difficult than category of "fair" that is not in the form of word problem (BNSP, 2014).

Responding to this issue, several studies had been conducted in Indonesia. Some studies focused on students' error analysis in solving word problems (Huda \& Kencana, 2013; Mulyadi, Riyadi, \& Subanti, 2015; Rahman, Uno, \& Nurwan, 2015; Rindyana \& Chandra, 2013). Interestingly, these studies found that linguistic difficulties; such as ability to understand vocabulary, translate daily vocabulary to mathematical expressions, and understand symbols; were predominantly found. These studies did not specifically discuss the linguistic difficulties although they were often found.

Other studies focused on experiments in using particular strategy to help students improving their performance to solve word problems. For example, the use of Polya's steps (Marlina, 2013), think-talk-write (Istiqomah, Poerwanti, \& Hadiyah, 2013), and problem-posing (Junaidah, Shaifuddin, Sadiman, \& Kamsiyati, 2015). Those studies were all motivated by the findings that students had linguistic difficulties in solving word problems. Despite the dominance of linguistic difficulties, these studies did not specifically discuss the relation between linguistic difficulties and the applied strategy. These 
studies merely compared students' performance, not linguistic difficulties, before and after the strategy being applied.

To better understand linguistic difficulties of word problem, it is important to understand the linguistic aspects constructing it; students who fail to understand the constructing aspects, will have difficulty in solving word problem. Word problem is constructed by three main aspects i.e. multiple representation system, vocabulary, and grammar and syntax (Lee, 2006; O’Halloran, 2010, 2015; Schleppegrell, 2007). These aspects become the character of word problem from language perspective. Difficulty due to multiple representation system refers to the difficulty to make meaning among the three systems: daily language, symbols, and visual representation. Difficulty due to vocabulary refers to difficulty to understand the meaning of vocabulary despite its location in the sentence. Difficulty due to grammar and syntax is the difficulty to make meaning of the whole sentence because of the structure of words in it or how the sentence is constructed.

Linguistic difficulty in solving word problems was not only found in basic mathematics topic, but also in high school topic like derivative. One study showed that in solving word problems of derivative, students could not understand vocabulary, which information to be used, or found the text to be confusing (Klymchuk, Zverkova, Gruenwald, \& Sauerbier, 2010). Another study investigated the difficulties in solving word problems of derivative specifically related to multiple representation system (Fatmanissa, Kusnandi, \& Usdiyana, 2019). This study found that students faced difficulties during word problem solving of derivatives in diverse cases involving transforming meaning among visual representation, symbol, and language.

In accordance to that, it is imperative to investigate specific strategy but focusing on how to help students facing linguistic difficulties in solving word problems. Schema-based strategy instruction is known to benefit students in exercising their ability to understand and apply the linguistic aspects of word problems. Schema is a framework, diagram, or plan that is used to organize information (Marshall, 1995). Schema can be in the form of diagram to organize information given in word problem visually (Jitendra et al., 2009) or in the form of parts and mathematical expression (Powell, Fuchs, Fuchs, Cirino, \& Fletcher, 2009).

Marshall (1995) conducted experiment by comparing experimental group (instructed to use schema) with control group to state the known information and meaning of the word problem. In this study, experimental group was proven to be able to determine correctly more known information and meaning of word problem. Besides, experimental group did not find it difficult to understand the relation among information in the text which means that they could understand meaning in the text and create it visually. This is inline with how students face their linguistic difficulty. Thus, the aim of this research is to analyze the effectiveness of schema in resolving difficulties based on linguistic aspects constructing word problem (multiple representation systems, vocabulary, and grammar and syntax), especially in derivative topic.

\section{METHOD}

Data was collected through a mixed method study with an embedded quasi-experimental model to test the effectiveness of schema use. The quantitative study was conducted using a pretest-posttest comparison group design, while the qualitative analysis was done to gain information on how students solve word problems in both groups. Groups being compared are treatment group that was taught to use schema and control group that was not.

Participants were 69 students of 11th grade; 33 belonged to the treatment group, while the rest belonged to the control group. The homogeneity of both groups was tested through a t-test for comparing means of pretest score obtained before the treatment $(p=0.775)$. Besides, to support whether socio-linguistic background of students in both groups were similar, survey of students' daily languages and ethnicity was conducted and showed no difference in both groups background.

Treatment class was taught to use schema to solve word problems, but control class was not. There was one instructor for both classes and taught both classes for 5 meetings ( 80 minutes each). Both classes were given pretest before the teaching periods and posttest after it. The topic for both classes was derivative.

The teaching design for both classes was different in several ways. The teaching design for the treatment group was in line with the schema process based on Powell (Powell, 2011) and Boonen et al. (Boonen, de Koning, Jolles, \& van der Schoot, 2016) shown in Figure 1. In the first meeting, students were exposed to how to read the problem by paying attention to the information given. In this stage, students were not demanded to make mathematical expression or even solve the problem, but more on identifying key words of information from the problem. For the second and third meeting, the focus was to have students exercise making appropriate schema in the form of picture or diagram and mathematical representation. The fourth and fifth meeting focused on making mathematical solution and interpret solution. While treatment class going through this process, control class was taught to solve word problems in derivative by reading, making plan, determining solution, and interpreting without being guided to utilize schema in that process.

Pretest and posttest were given in the form of six essay questions. The test for both classes was conducted in the same day to avoid questions leak. Students could use calculator during the test considering the aim for the test was not calculation skill. The test items were constructed with the goal to check whether the aspects of linguistic difficulties appeared. The test items readability and clarity were consulted to two mathematics education experts. Test items validity was confirmed by using Spearman test (all items significant value < 0.05 ) and the reliability by using Cronbach Alpha coefficient (pretest = 0.576 ; posttest $=0.558$ )

Student's work was analyzed by first giving code(s) of aspect of linguistic difficulties which appeared. The codes were "MRS" (for multiple representation system), "V" (for vocabulary), and "GS" (for grammar and syntax). The codes were recorded, counted, and students' works were classified based on it. After being classified, distinct cases of difficulty in each code were further explored through interview.

\section{RESULT}

The effect of schema teaching was analyzed by checking whether the teaching of using schema helped students to face their linguistic difficulties based on each aspect (i.e. multiple representation system, vocabulary, and grammar and syntax). This was done by comparing the number of difficulties between treatment and control group found in 


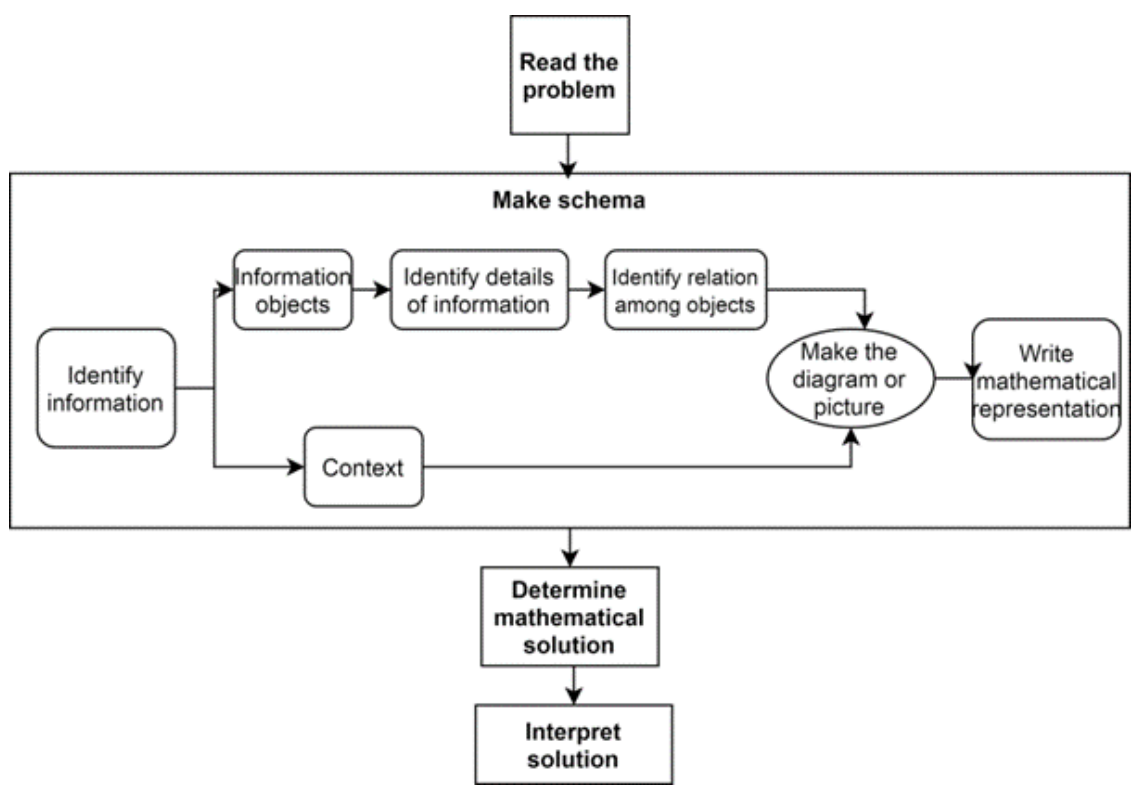

Figure 1. Schema making

Table 1. Mann-Whitney test result and effect size by each aspect

\begin{tabular}{ccc}
\hline Aspect of difficulty & $\boldsymbol{p}$ & ES \\
\hline Multiple Representation System & .007 & .432 \\
\hline Vocabulary & .048 & .508 \\
\hline Grammar and syntax & .000 & .978 \\
\hline
\end{tabular}

the posttest. Given that the pre-treatment equivalency test showed no significant difference between two groups ( $p=0.775$ ), showing the same 'starting point' between groups, analyzing this through posttest was adequate. The quantitative analysis was done by having statistics tests and calculating effect size. The data being used was the number of difficulties found in each aspect on pretest and posttest.

Statistic test being used to compare the number of difficulties between treatment and control group was Mann-Whitney test since the data was not normally distributed. The $p$-value obtained from
Mann-Whitney tests $(p)$ and the effect size (ES) for each aspect are given in Table 1.

Between groups, there was a significant difference of difficulties based on each aspect. Treatment group showed significantly less difficulties in multiple representation system $(p=0.007)$, vocabulary $(p=0.048)$, and grammar and syntax $(p=0.000)$ aspect. This showed that schema teaching was helpful for students in facing linguistic difficulties during word problem solving. The effect sizes for all aspects showed moderate (for MRS and vocabulary aspect) and strong effect (for grammar and syntax aspect). It can be inferred that the schema teaching helped students on facing linguistic difficulties, especially due to the complexity of grammar and syntax of the word problem.

In order to gain more demonstration of how schema teaching benefit treatment group, two cases were chosen to analyze it further. Student A (control group) and Student B (treatment group) were

Translated problem: 5. Given a piece of square board with side length of $12 \mathrm{~cm}$. A square piece of cardboard is cut equally from each board corner. (a) draw the picture of the board;

(b) After being cut and formed into a topless box, determine the maximum volume of the box.

5. Diketahui secarik kertas berbentuk persegi dengan sisi $12 \mathrm{~cm}$. Kertas tersebut dipotong ujt berbentuk persegi yang ukurannya sama.

a. Gambarkanlah bentuk kertas tersebut.

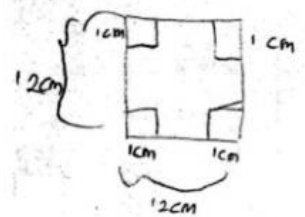

Setelah dipotong, kertas tersebut dibentuk menjadi kotak tanpa tutup. Tentukan volume m

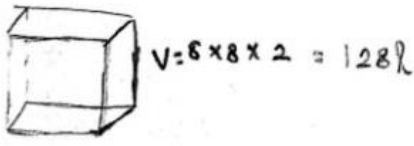

Diketahui secarik kertas berbentuk persegi dengan sisi $12 \mathrm{~cm}$. Kertas tersebut dip berbentuk persegi yang ukurannya sama.

a. Gambarkanlah bentuk kertas tersebut.

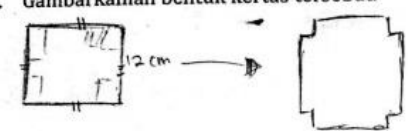

5. Setelah dipotong, kertas tersebut dibentuk menjadi kotak tanpa tutup. Tentukan v

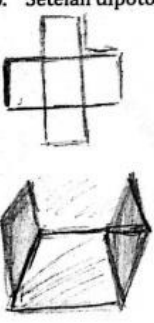

Student A

Student B

Figure 2. Representative example of average student of treatment group compared to control group 
Translated problem: 4. A particle is observed in the interval $0 \leq t \leq 6$ (in minutes). The particle displacement is defined by a function $f(t)=$ $t^{3}-9 t^{2}+24 t-16$. Explain the particle displacement 2 minutes before, at, and 2 minutes after the maximum displacement.

4. Sebuah partikel diamati pada interval waktu $0 \leq t \leq 6$ (dalam menit). Perpindahan partikel tersebut dinyatakan dalam fungsi $f(t)=t^{3}-9 t^{2}+24 t-16$. Jelaskan perpindahan partikel tersebut 2 menit sebelum, saat, dan 2 menit sesudah perpindahan maksimalnya.

('(t) $=y^{2}-: 3 t+24=0$

$\frac{1}{3}(1,2-6)(3, t-8)=0$

$(t-3)(3 t-8)$

$i \quad$ L. 2.0 .0

$t=3 \quad t \cdot \frac{8}{3}$

$f(3) \cdot 3^{3}-9(3)^{2}+24(3) \cdot 16$

. $27.81+72.16$

$=22$ (maks)

- 2 menit sebelum

(2 minutes before)

$(0 / 3) \cdot 0 / 3^{3}-9(0 / 5)^{2}+24(0 / 3)-16$

$f(1)=1^{3}-9 \cdot 1^{2}+29 \cdot 1-16$

$=1-9+24-16$.
$=0$

2 menit sesclah

( 2 minutes after)

$=\frac{122}{3}-\frac{5 \%}{3}+\frac{192}{3}-6$

$=-\frac{192}{3}-\frac{40}{3}=\frac{-240}{3} \cdot .(\mathrm{min})$

$f(5)=5^{3}-9(5)^{2}+24.5-16$

$=125-225+120-16$

$\times 4$

Student C

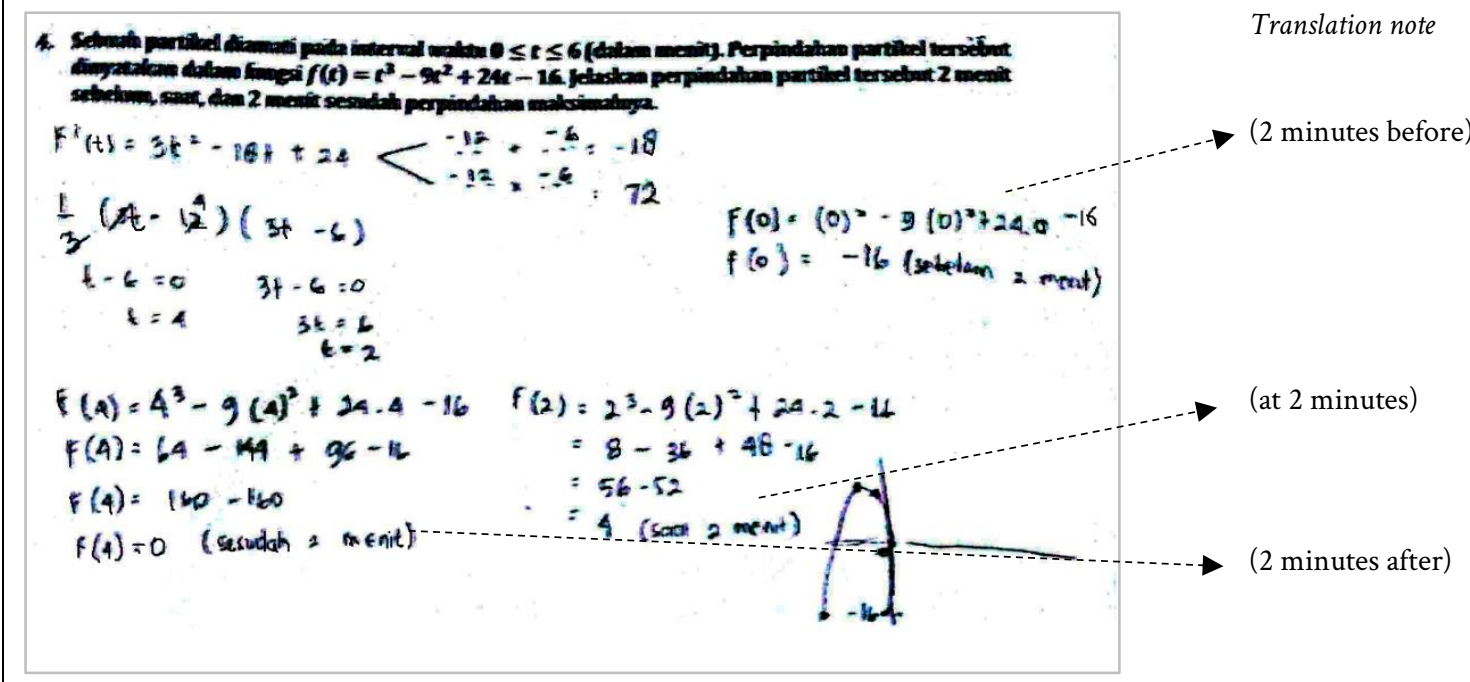

Student D

Figure 3. Representative example of high scorer of treatment group compared to control group

students with average score on pretest and chosen as representative examples on how schema teaching benefit students with average ability. Figure 2 displays the work of Student A and Student B on posttest no. 5. In Figure 2, both students were asked to determine the maximum volume of a box that is made from a board whose corners are cut. Both student $\mathrm{A}$ and student $\mathrm{B}$ could make the visual representation of the board. However, when starting to determine the maximum volume, they showed different works. Student A, although not correct, directly determine that the length of the square side being cut was $2 \mathrm{~cm}$. Then, she determined the volume by understanding that the box was a cuboid. On the other hand, student B could not determine how "topless box" looked like, although managed to show the net.

In this example, student A showed more ability in understanding the textual description of the box in the problem compared to student B. In other words, student A show more ability on transforming textual information into visual representation. Despite not being able to solve the problem, student A displayed her work direction, which was to determine the volume, and the size of cuboid being calculated was appropriately related to the visual representation she made. This can be understood since student A was accustomed to the teaching using schema that made her exercise to draw diagram based on textual information in the problem.

Interesting finding was also found from the work of two students (Student C and Student D) in posttest no. 4 as displayed in Figure 3. In this problem, students were asked to explain the particle displacement 2 minutes before, at, and 2 minutes after the maximum displacement. The correct answer is determined by how students can find that the maximum displacement happens at the second minute of displacement. Thus, particle displacement 2 minutes before the maximum displacement is the displacement at the minute of 0 , and displacement 2 minutes after the maximum displacement is the displacement at the minute of 4 .

Slightly seen, the work of student $D$ was more accurate than student $\mathrm{C}$ as student $\mathrm{C}$ incorrectly determine the factor of $f^{\prime}(t)$, resulting on incorrectly determining when the particle would have maximum displacement. However, the following transcript of them when being asked about their ways of thinking showed more finding. 


\section{Student C} Student D

Translation: "I plugged in 3 to the function from this (pointed at the factorization). This is the minute at

Translation: "I just predict, mam. I differentiate, I get 2 and 4 . Then I just plugin. maximum (displacement). This is used Then at the problem I saw 0 for the maximum. Then, 2 minutes $\quad \leq \mathrm{t} \leq 6$, so I think 0 should before means 3 minus 2 is minute of 1 , also be plugged in. So, just 2 minutes after means we plugin 5." like that, I predict"

Interview transcript of the two students showed the fact that student $\mathrm{C}$ understood the meaning of the problem sentence more and understood the reason behind his steps. Student D, despite correctly answered the problem, stated that he chose the value of $t$ based on prediction from the derivative and from the interval given in the problem, but his prediction showed no logical reason behind it Students of treatment group was evidenced to be more self-directed toward the problem goal and understand the meaning of the sentences in the problem.

\section{DISCUSSION}

Quantitative analysis showed that schema is effective in helping students facing linguistic difficulties in each aspect of difficulty. The effectivity of schema in helping students was also found in several studies (Boonen, Van Wesel, Jolles, \& Van der Schoot, 2014; Hegarty \& Kozhevnikov, 1999; Skemp, 1987; Xin, Jitendra, \& Deatline-Buchman, 2005). In Multiple Representation System aspect, schema is proven to be effective in helping students transforming meaning across representation system in solving word problems, a result similar to study by Saenz-Ludlow \& Kadunz (2016).

Despite being proven statistically effective, the effect size of grammar and syntax aspect was found to be greater than multiple representation system and vocabulary aspect. This leads to another discussion of possible underlying reason. Strong effect on difficulties related to grammar and syntax aspect was manifested into more understanding on problem sentences. The finding of stronger understanding of sentences is also agreed by the study of Jitendra et al. (2009). In the study, the duration of treatment was given twice longer than this study, leads to note that greater effect may be obtained if the teaching duration is prolonged. The study also emphasized the need of extensive exposure to treatment for strong effect. Supporting this statement, understanding sentences can be helped using schema, as highlighted by Xin et al. (2005), but intensive teacher-student discussion is also needed so that students do not get used to catch shallow meaning of sentence.

More self-directed students after being taught to use schema is supported by the study of Hegarty and Kozhevnikov (1999). The study found that schema teaching indeed helps students to create strategy and construct reason behind it. However, in practice, the teaching may not maximally utilize the use of schema in facilitating exercises, which in several studies were found to be effective in familiarizing students with word problem (Chan, 2015; Jacoby, 1978).

\section{CONCLUSION}

In general, schema is proven to be effective in helping students solve word problems. Schema teaching is also effective in resolving mathematical linguistic difficulties during word problem solving in all aspect of linguistic difficulties (i.e. multiple representation system, vocabulary, and grammar and syntax). Adding to that, students being taught schema showed more attention and application upon the whole sentence or information provided by the problem and were more selfdirected in determining solving steps towards problem goal.

This study further offers an alternative strategy, which is schema teaching, that is more directed on linguistic difficulty in solving word problems. Besides, this study also offers empirical findings to support a strategy that might be used for high school students on a more complex mathematics topic like derivative.

This study does not claim that schema teaching will benefit all types of students on all mathematics topics due to its participants selection and mathematics topic limitation. Responding to that, it is hoped that in the future, studies on word problem, linguistic difficulties, and schema teaching will be more expanded, for example by investigating more mathematics topics or different types of students.

\section{REFERENCES}

BNSP. (2014). Laporan Hasil Ujian Nasional Tahun 2014 (Vol. 12).

Boonen, A. J. H., de Koning, B. B., Jolles, J., \& van der Schoot, M. (2016). Word Problem Solving in Contemporary Math Education: A Plea for Reading Comprehension Skills Training. Frontiers in Psychology, 7(February), 191. https://doi.org/10.3389/fpsyg.2016. 00191

Boonen, A. J. H., Van Wesel, F., Jolles, J., \& Van der Schoot, M. (2014). The role of visual representation type, spatial ability, and reading comprehension in word problem solving: An item-level analysis in elementary school children. International Journal of Educational Research, 68, 15-26. https://doi.org/10.1016/j.ijer.2014.08.001

Chan, S. (2015). Linguistic challenges in the mathematical register for EFL learners: linguistic and multimodal strategies to help learners tackle mathematics word problems. International Journal of Bilingual Education and Bilingualism, 18(3), 306-318. https://doi.org/10.1080/13670050.2014.988114

Fatmanissa, N., Kusnandi, \& Usdiyana, D. (2019). Student difficulties in word problems of derivatives: A multisemiotic perspective. Journal of Physics: Conference Series, 1157(3). https://doi.org/10.1088/1742$6596 / 1157 / 3 / 032111$

Hegarty, M., \& Kozhevnikov, M. (1999). Types of visual-spatial representations and mathematical problem solving. Journal of Educational Psychology, 91(4), 684-689. https://doi.org/10.1037/ 0022-0663.91.4.684

Huda, N., \& Kencana, A. G. (2013). Analisis Kesulitan Siswa Berdasarkan Kemampuan Pemahaman dalam Menyelesaikan Soal Cerita pada Materi Kubus dan Balok Di Kelas VIII SMP Negeri 30 Muaro Jambi. Prosiding Semirata FMIPA Lampung, 1, 595-606.

Istiqomah, N., Poerwanti, J., \& Hadiyah. (2013). Penerapan Strategi Pembelajaran Think-Talk-Write (TTW) Untuk Meningkatkan Keterampilan Menyelesaikan Soal Cerita Pecahan. Didaktika Djiwa Indria, 3(8), 1-8. 
Jacoby, L. L. (1978). On interpreting the effects of repetition: Solving a problem versus remembering a solution. Journal of Verbal Learning and Verbal Behavior, 17(6), 649-667. https://doi.org/10.1016/ S0022-5371(78)90393-6

Jitendra, A. K., Star, J. R., Starosta, K., Leh, J. M., Sood, S., Caskie, G., ... Mack, T. R. (2009). Improving seventh grade students' learning of ratio and proportion: The role of schema-based instruction. Contemporary Educational Psychology, 34(3), 250-264. https://doi.org/10.1016/j.cedpsych.2009.06.001

Junaidah, Shaifuddin, M., Sadiman, \& Kamsiyati, S. (2015). Penerapan Model Pembelajaran Problem Posing Tipe Pre- Solution Posing Untuk Meningkatkan Keterampilan Menyelesaikan Soal Cerita Tentang Bangun Datar Dan Bangun Ruang. Jurnal FKIP UNS, 5(3), 106-110.

Klymchuk, S., Zverkova, T., Gruenwald, N., \& Sauerbier, G. (2010). University students' difficulties in solving application problems in calculus: Student perspectives. Mathematics Education Research Journal, 22(2), 81-91. https://doi.org/10.1007/BF03217567

Lee, C. (2006). Language for Learning Mathematics: Assessment for Learning in Practice. New York: Open University Press.

Marlina, L. (2013). Penerapan Langkah Ploya dalam Menyelesakan Soal Cerita dan Luas Persegi Panjang. Elektronik Pendidikan Matematika Tadulako, 01, 43-52.

Marshall, S. P. (1995). Schemas in problem solving. Cambridge: Cambridge University Press. https://doi.org/10.1017/ CBO9780511527890

Mulyadi, Riyadi, \& Subanti, S. (2015). Analisis Kesalahan Dalam Menyelesaikan Soal Cerita Pada Materi Luas Permukaan Bangun Ruang Berdasarkan Newman'S Error Analysis Ditinjau Dari Kemampuan Spasial. Elektronik Pembelajaran Matematika, 3(4), 370382.

O'Halloran, K. L. (2010). The Semantic Hyperspace: Accumulating Mathematical Knowledge across Semiotic Resources and Modalities. In K. Christie, F. \& Maton (Ed.), Disciplinarity: Functional Linguistic and Sociological Perspectives (pp. 217-236). London: Continuum.

O'Halloran, K. L. (2015). The language of learning mathematics: A multimodal perspective. Journal of Mathematical Behavior, 40, 63-74. https://doi.org/10.1016/j.jmathb.2014.09.002

Powell, S. R. (2011). Solving Word Problems Using Schemas: A Review of the Literature. Learning Disabilities Research \& Practice, 26(2), 94108. https://doi.org/10.1111/j.1540-5826.2011.00329.x
Powell, S. R., Fuchs, L. S., Fuchs, D., Cirino, P. T., \& Fletcher, J. M. (2009). Affect Problem Difficulty as a Function and Without Reading Difficulty? Journal of Learning Disabilities, 99-111. https://doi.org/10.1177/0022219408326211

Raharjo, M. (2008). Pembelajaran soal cerita berkait penjumlahan dan pengurangan di SD. Pusat Pengembangan dan Pemberdayaan Pendidikan dan Tenaga Kependidikan Matematika, Yogyakarta.

Rahman, R., Uno, H. B., \& Nurwan. (2015). Analisis kesulitan siswa dalam menyelesaikan soal cerita pada materi KPK dan FPB di kelas VII SMP Negeri 1 batudaa. Universitas Negeri Gorontalo.

Reys, R., Lindquist, M., Lambdin, D., \& Smith, N. (2013). Helping Children Learn Mathematics.

Rindyana, B., \& Chandra, T. (2013). Analisis Kesalahan Siswa Dalam Menyelesaikan Soal Cerita Matematika Materi Sistem Persamaan Linear Dua Variabel Berdasarkan Analisis Newman (Studi Kasusman Malang 2 Batu). Artikel Ilmiah Universitas Negeri Malang, 1(2), 1-9. https://doi.org/10.36706/jls.v1i2.9707

Ryan, J., \& Williams, J. (2007). Children's Mathematics: Learning from Errors and Misconceptions. Berskhire: McGraw Hill.

Saenz-Ludlow, A., \& Kadunz, G. (2016). Semiotics as a Tool for Learning Mathematics: How to Describe the Construction, Visualization, and Communication of Mathematical Concepts. Rotterdam: Sense Publisher. https://doi.org/10.1007/978-94-6300-337-7

Schleppegrell, M. J. (2007). The linguistic challenges of mathematics teaching and learning: A research review. Reading and Writing Quarterly, 23(2), 139-159. https://doi.org/10.1080/1057356060 1158461

Skemp, R. R. (1987). The Psychology of Learning Mathematics. New Jersey: Psychology Press.

Sutarni, M. (2011). Penerapan Model Pembelajaran Konstruktivisme untuk Meningkatkan Hasil Belajar IPA. Jurnal Pendidikan Penabur, 16(Jun), 26-33. https://doi.org/10.1017/CBO9781107415324.004

Verschaffel, L., van Dooren, W., Greer, B., \& Mukhopadhyay, S. (2010). Reconceptualising Word Problems as Exercises in Mathematical Modelling. Journal Fur Mathematik-Didaktik, 31(1), 9-29. https://doi.org/10.1007/s13138-010-0007-X

Xin, Y. P., Jitendra, A. K., \& Deatline-Buchman, A. (2005). Effects of Mathematical Word Problem Solving Instruction on Middle School Students with Learning Problems. The Journal of Special Education, 39(3), 181-192. https://doi.org/10.1177/00224669050 390030501 